\title{
REVOLUTIONARY EUROPE AND THE DESTRUCTION OF JAVA'S OLD ORDER, 1808-1830
}

\author{
Peter Carey ${ }^{1}$
}

\begin{abstract}
At first glance, it may seem strange that Java, an island situated half a world away from France Revolutionary, should the end up being one of the key battle grounds in the global conflict which followed with the fateful Girondin decision to declare war on Austria in the spring of 1792. Yet, in the compass of less than a decade, Java's own ancient regime that was violently overturned as in quick succession of a FrancoDutch regime (1808-11) under Napoleon's only non-French marshal, Herman Willem Daendels (1762-1818), and a five-year British occupation (1811-1816) under the equally dictatorial Sir Thomas Stamford Raffles (1781-1826), transformed the colony. This paved the way for the restoration of Dutch rule in 1816 under the terms of the Treaty of Vienna by which time the commercial dealings of the Company had been replaced by the beginnings of a modern colonial state, the post-January 1818 Netherlands Indies. Over the next century, this would reduce the power of the local rulers and establish Dutch authority in nearly every corner of the archipelago. The boundaries of presentday Indonesia were determined at this time.
\end{abstract}

Key Words: revolutionary, destruction of Java

\section{Introduction}

Java's destiny had long been linked to the emerging of global economy through the Dutch connection and the international business networks of the overseas Chinese. These latter on became the key to the Dutch management of a complex trading system which underpinned the wealth of the failing Dutch East India Company (Vereenigde Oost Indische Compagnie; henceforth: VOC) in Asia. Java's rice and textile exports sustained the Company's original trading bases in the Spice Islands (Ambon, Banda, Ternate and Tidore) while its commodity exports - in particularly coffee from West Java, and indigo and sugar were from the Bataviasche Ommelanden (Batavian hinterland) developed with overseas Chinese capital - had begun to make their mark on world markets. Java was also a major rendez-vous point for Dutch trade from its factories in Surat, Malabar and Nagasaki as well as a potential military strongpoint in the Indian Ocean that had given its extensive dockyards at Pulau Onrust in the Bay of Batavia and its port

1 Peter Carey, Ph.D, is a British historian and author who studies East Timor, Java and Burma. He was the Laithwaite fellow of Modern History at Trinity College, Oxford. His major early work has concentrated on the history of Diponegoro, the British in Java and the Java War. For academic interest, the author can be contacted trough email address at: peterbrcarey@hotmail.com. 
and shipbuilding facilities along Java's north coast. Such assets were a tempting prize for both the French Republic and the Republic's First Coalition enemies, in particular Britain.

Despite its commercial and military importance, however, the island, whose estimated population was some 3.5 million in 1795 (Nederburgh census), was not a Dutch version of the British Raj. A declining power in Europe, Holland appeared to be on its way out in Java while the south-central Javanese rulers in Yogyakarta and Surakarta enjoyed de facto sovereignty. The Fourth Anglo-Dutch War of 1780-1783 was the turning point. Faced with mounting debts, the VOC was declared bankrupt and its assets taken over by the Dutch state on 1 January 180o. By then control of the Dutch possessions in the East had been taken out of the hands of the Directors of the VOC and vested in the new Committee for the Affairs of East Indian Trade and Colonies, a creation of the new Batavian Republic (1796-1806) formed after Holland's incorporation in the French Grande Nation when General Jean-Charles Pichegru's Army of the North had crossed the Dutch Republic's frozen Maas and Waal rivers and installed a pro-French regime in The Hague (January 1795).

News of these dramatic events in Europe and their implications for Java's old order were slow to percolate through to the distant archipelago. The fact that VOC personnel, scions of the great mestiço Indies families who were then politically preeminent in Java, continued in post well beyond Daendels' administration (1808-11) meant that the local Javanese rulers had difficulty in getting a true insight into the scale of the political revolution which was then transforming Europe. Holland's weakness masked political realities. Indeed, the fact that the Dutch governor-general and Council of the Indies felt the need to appeal to the south-central Javanese rulers to help them to defend their colonial capital - Batavia - during the international crises which sped the VOC's demise, reinforced the courts' suspicion that the Dutch were on their way out militarily in the Indies.

Following Holland's occupation in 1794-5, the Stadhouder (Head of State), William V (reigned, 1766-85/1787-95), fled to London and from his place of exile in the royal palace at Kew issued the so-called 'Kew Letters' which ordered that the Republic's colonies be handed over to the British to prevent them falling into French hands. So began a twenty-year period in which the East Indies was drawn into the global conflict between Britain and France. During this period of the Revolutionary (1792-99) and Napoleonic (1799-1802/1803-13/1815) wars, the archipelago became a battle ground on land and sea. Between 1795 and 1797, British naval forces operating from Madras and Pinang island captured most of the Dutch possessions outside Java. Although returned to Holland under the terms of the Peace of Amiens (1802), all were recaptured by the British in the seven years which followed the renewal of hostilities in Europe in May 1803. During this time the East Indies were placed under strict naval blockade, an interdiction so tight that Napoleon's younger brother, Louis Bonaparte (King of Holland, 1806- 
10) took care to send Daendels out to Java with a replacement to the governorgeneral following on a separate fast frigate in case he fell into British hands.

The tragedy for the Javanese was that just as all the signs seemed to point in the direction of a Dutch collapse, half a world away in Europe events were taking place which would change the Javanese 'Old Order' for ever. The twin political and industrial revolutions then tearing the ancien régimes of eighteenth-century Europe apart would hit Java with the force of an Asian tsunami. In the space of just four years (1808-1812), the relationship between the European government and the south-central Javanese rulers was transformed. The Yogyakarta sultanate bore the brunt of these changes. In quick succession, the re-energised FrancoDutch regime of Daendels (1808-11) and the British-Indian administration of Raffles (1811-16) forced open Yogyakarta's eastern outlying territories, plundered its court and exiled its reigning monarch. After the fall of the kraton (fortified royal capital/court) in June 1812 and the imposition of new treaties, the relationship between Batavia and the princely states began to resemble post-Plassey India when the British replaced the Mughal emperors in Lower Bengal. The returned Dutch administration of Governor-general Godert Alexander Gerard Philip Baron van der Capellen (in office, 1816-1826) continued this process. Desperate for money but keen to protect the welfare of ordinary Javanese, Van der Capellen's attempts to square the circle between increased fiscal returns and his ethical principles ignited a powder-keg in south-central Java. Adverse environmental and health conditions, in particular the May 1821 cholera epidemic and the December 1822 eruption of the central Javanese Mount Merapi volcano, combined with soaring rice prices, triggered massive popular uprisings in July-August 1825 which heralded the outbreak of the Java War (1825-30).

This conflict was a watershed in the history of Java and of what - post1945 - would become the Republic of Indonesia. For the first time a European colonial government faced a social rebellion covering a large part of the island. Likewise, the Javanese experienced for perhaps the first time a rebellion which had at its heart social and economic grievances rather than dynastic ambitions. Most of central and east Java, and many of the north coast areas were affected. Two million Javanese, nearly half the island's total population, were exposed to the ravages of war, one fourth of the cultivated area of Java sustained damage and about 200,000 Javanese died. In securing their pyrrhic victory, the Dutch also suffered: 7,000 Indonesian auxiliaries as well as 8,000 of their own troops perished.The war cost their exchequer an estimated 20 million guilders. The end of the conflict left the Dutch in undisputed control of the island and a new phase of colonial rule began with the inception of Governor-general Johannes van den Bosch's 'cultivation system' (1830-1870). This turned Java into a globallylinked cash crop economy, a development which proved immensely profitable for Holland with an estimated 880 million guilders (present-day US $\$ 100$ billion) accruing to the Dutch exchequer, easing the Netherlands transition to a modern industrial economy. The war thus marked the end of a process, maturing since 
the Daendels' administration (1808-1811), which saw the change-over from the Dutch East India Company era, when contacts between Batavia and the southcentral Javanese kingdoms had had the nature of ambassadorial links between sovereign states, to the 'high colonial' period when the Principalities occupied a clearly subordinate position to the European power.

For the Javanese, this five-year conflict had far-reaching implications. The emergence of a strong charismatic leader in the person of Pangéran (prince) Diponegoro (1785-1855), who took the title of the Javanese messianic ratu adil ('just king'), served to bring many disparate social elements under the single banner of Javanese Islam. Widespread millenarian expectations caught the imagination of the peasantry and acted as a catalyst for social and economic grievances, accumulating since the beginning of the nineteenth century. The concept of holy war (perang sabil), imagery from the Javanese shadow-play (wayang), and Javanese nativist sentiments, made up of an intense longing for the restoration of an idealized traditional order - which Diponegoro described as 'restoring the high state of the Islamic religion in Java' - all forged a common identity amongst the prince's followers. In this fashion, nobles, dismissed provincial officials, religious teachers, professional bandits, porters, day labourers, tax-paying farmers (sikep) and artisans were brought together briefly in a common cause. The Java War was thus significant for Indonesia's future. The subtle interplay of economic grievances and millenarian hopes created a movement of unique social breadth which anticipated the nationalist movement of the early twentieth century.

The cultural dislocation wrought by the new European imperialism shaped the young Diponegoro. A key transitional figure, he lived through the shift from the old order of late eighteenth century Java to the new 'high colonial' era when steamships plied the trade routes of the Netherlands-Indies archipelago linking Diponegoro's place of exile in Sulawesi (Celebes) to the main Javanese ports. A traditional figure steeped in the values of pre-modern Java, particularly the spirit world of the south-central Javanese courts, he also pointed to the future. One thinks here of his use of Javanese Islam, particularly its millenarian traditions, as a way of forging a new identity for Javanese Muslims in an era when the old Javanese order was crumbling.

Diponegoro inhabited a world increasingly divided between those who were prepared to accommodate themselves to the new European dispensation and those who saw the Islamic moral order (agama Islam) as the lodestar in a society which had lost its traditional moorings. The Java War thus gave impetus to a process still working itself out in present-day Indonesia, namely, the integration of Islamic values into contemporary Javanese and Indonesian identity. Diponegoro's world view also encompassed a distinctly contemporary concern with how Javanese Muslims should live in an age of Western imperialism. For the prince, unlike most present-day Indonesian Muslims, the answer lay in the waging of holy war and the development of a clear distinction between the wong Islam ('people of Islam'; Muslim believers), the European kapir laknatullah (heretics accursed by 
Allah), and the Javanese kapir murtad (apostates), namely those who had allied themselves with the Dutch. There was also a concern on the prince's part for the preservation of specifically Javanese values as expressed in language, dress and cultural codes. This can be seen most clearly in his treatment of Dutch prisoners and his insistence that they adopt Javanese dress and speak to their captors not in the reviled language of the new colonial state - 'service Malay' - but in High Javanese (krama), the medium of the court elite (Hoffman, 1979: 85-92).

Despite his adoption of Ottoman dress and bestowal of Ottoman military titles - Basah ('Pasha') and Ali Basah ('The High Pasha') - on his military commanders, Diponegoro was no Islamic reformer. A traditional Javanese Muslim, he had no problem reconciling the spirit world of Java with membership of the international ummat (community of Muslim believers) whose religious and politico-cultural centres lay in the Hejaz (present-day Saudi Arabia) and Ottoman Turkey. Although Diponegoro did not prevail in achieving his goal of restoring the high state of the Islamic religion in Java, his wider moral vision of securing an honoured place for Islam in the life of the nation had a lasting resonance. Indeed, following Indonesia's political independencefrom the Dutch in 1945, it has continued to be negotiated, especially in the current post-9/11 world of global conflict between what some in the Islamic community perceive as the 'materialistic' values of the West and what many more - believers and unbelievers alike - acknowledge as the deeply fissiparous loyalties of the worldwide Muslim ummat.

\section{Daendels' Political Revolution, 1808-1811}

The 'beginning of the ruin of the Land of Java' had been the prophetic warning delivered to Diponegoro during a pilgrimage to visit Java's spirit guardians on the south coast in circa 1805 . Specifically, he had been told that this destruction would start in just under three years' time. Right on cue, on 5 January 1808, Daendels arrived in Batavia to take up his post as governorgeneral. Lawyer, revolutionary, politician and career soldier, he was very much a product of the new Europe forged by the French Revolution. A participant in the 'Patriot Revolt' against the Stadhouder in Holland (1786-1787), he had helped set up (and commanded) the Batavian Legion (1792-95) which had fought alongside French Republican forces in the 1794-5 invasion of the Dutch Netherlands. Later, as head of the pro-French Unitarian Party, he had earned himself a reputation as a 'headstrong, sentimental and obstinate' character (Schama, 1977: 342-343). A man of few scruples, great energy and a penchant for using force to achieve his political ends, he was destined to make a lasting mark on the history of Java.

One of the Marshal's primary strategic considerations in planning Java's defence was the position of the independent courts. Their power and influence marked them out as potential rivals to the European government and as dubious allies in the event of an enemy attack. In this respect, the court of Yogyakarta was by far the more redoubtable in the light of its military resources and substantial 
cash reserves. Imbued with a fierce hatred of ancien regime monarchies, Daendels promulgated a celebrated Edict on Ceremonial and Etiquette on 28 July 1808, which did away with most of the ceremonial functions previously performed by the Residents for the rulers which were considered degrading. Instead, the new Franco-Dutch regime accorded them various privileges more in line with their positions as direct representatives of the governor-general and the royal government in The Hague (Carey, 2008: 166, Daendels, 1814: 94). Thus the First Residents now received the title of 'Minister' with new Napoleonic era uniforms (blue coats with high collars braided in gold with olives, olive branches and flat gold buttons, white breeches with embroidered knee bands and white silk stockings, and tricorn black hats with black straps and cockade), and were allowed to carry a blue and gold state parasol or payung emblazoned with the arms of the King of Holland. On official occasions, they were not to remove their hats when approaching the ruler, who was to rise to greet the Dutch representative and make space for him immediately to his left on his throne, thus allowing him to sit at exactly the monarch's level. Likewise, they were no longer required to serve the ruler in a menial fashion with drink and betelnut. Various other articles regulated the new forms of greeting when saluting the ruler both inside and outside the kraton: the Minister, for example, was now accorded a military escort of mounted dragoons on all official visits to the court and was no longer expected to stop his coach when passing that of the ruler on the high road. Such changes in ceremonial amounted to a very substantial alteration to the position of the Dutch representatives at the courts which struck at the heart of the Javanese understanding of the Dutch presence in Java.

The edicts effectively destroyed the finely balanced political structure which enabled the courts' acceptance of Dutch rule in Java . If the articles of the edicts were carried out as the marshal wished there could no longer be any pretence that the Resident was a joint servant of the European government and the ruler. Even the diplomatic skills of the former VOC officials posted to the courts could not disguise the scale of the changes now being demanded. The Yogyakarta court chronicle describes how immediately upon receipt of the edict, the sultan ordered his throne to be changed in order to maintain his more elevated position during state functions. This involved making it narrower so that only the ruler could sit on it, and having a wooden footstool placed under it so that he would always sit higher than the Resident even when he went to visit him in the Residency, a procedure which nearly resulted in an armed clash between the sultan's entourage and British officers in the Residency 'throne room' at the time of Raffles' visit to Yogyakarta on 27 December 1811 (Carey, 2008: 309-310).

The political pressure now bearing down on the south-central Javanese rulers to accept their changed status opened up deep divisions at the courts. Those who were prepared to work with the European government began to display their pro-Dutch views in striking sartorial and personal ways. During his May 1803 inspection tour through south-central and east Java, the governor of Java's 
Northeast Coast, Nicolaus Engelhard (in office, 1801-1808), had already noticed that the Surakarta ruler's court was beginning to dress 'in European style' despite the huge debts this entailed (de Jonge and M.L. van Deventer, 1888: 128). Even in the more traditional Yogyakarta court, the value of adopting the cultural as well as political fashions of Java's foreign rulers was noted. The Crown Prince, who would rule briefly (1812-1814) as sultan under the British, sought to prove his pro-Dutch sentiments by insisting that his tea should be served with milk like that of his Dutch guests (Carey, 1992: 467), and crying out at the top of his voice during a military review in honour of visiting Dutch officers that Yogyakarta courtiers and officials should speak nothing else but Malay on that day 'because that was the language which the sultan's friends, the Dutch, used with their people!' (Carey, 2008: 180).

Attempts by Daendels and his senior officials to make the Javanese rulers understand that the marshal's edicts were part of a pan-European republican movement to overthrow the 'feudal order' fell on deaf ears. So baffling indeed was Daendels' language about the abolition of feudalism that the official Javanese translator in Semarang had great difficulty rendering the Dutch text into Javanese when the prime ministers of the two south-central Javanese courts came to the north coast port city to present their official compliments to the newly arrived governor-general.

'I receive with much pleasure and sincerity the homage of the [Surakarta ruler] through his prime minister and further ambassadors.

I do not consider this solemnity in the light of homage by a vassal to his lord paramount, the feudal system having been abolished in Europe, but I look upon the same as congratulations on my safe arrival on this island and on the commencement of the administration of His Majesty's possessions in India.

The [Dutch] East India Company and the Republic of the United Provinces had lost their former influence in Europe. But the election of the Emperor's brother to the throne of Holland has caused the political influence of that country to be re-established by adopting a more energetic mode of administration and by a most intimate union with the mightiest Empire in the world. It is the wish of King Louis to promote the happiness of his subjects on the island of Java and he offers them peace, prosperity and a benevolent government.

And I do solemnly declare in the name of His Majesty, the friend and protector of the princes and inhabitants of Java, that I will endeavour to maintain peace and to render the island of Java as prosperous as possible (Carey, 2008: 199).

As the prime ministers and their respective parties made their way back to the south-central Javanese courts with Daendels' declaration in their hands, 
they must have wondered what exactly was going on. A post-feudal Java? The happiness of subjects? The mightiest empire in the world? How to make sense of all this in the context of an 'Old Order' in Java which had seemed so immutable?

Luckily, symbolic explanation was at hand. No sooner had the Yogyakarta delegation returned home, than Daendels' deputy, Jacob Andries van Braam (1771-1820), came over from Surakarta on an official visit with his wife. It was usual on such occasions for the court to honour their distinguished guest with a tiger and buffalo fight on the southern alun-alun (open field behind the kraton). Van Braam was not disappointed (Houben, 1994, Ricklefs, 274-276, Carey, 1992: 467). However, the particular fight he witnessed had an interesting denouement: in the first round of the contest, the tiger severed the leg tendons of the buffalo and then refused to fight further. In the second, when a new tiger was introduced, it jumped clean out of the ring of guarding spearmen and was only caught and killed behind the elevated platform on which the sultan was sitting with his Dutch guest. 'This situation, which had never occurred before', Van Braam reported to Daendels, 'caused the Javanese to make many conjectures with regard to me [...] and the sultan made me a compliment and said that it had occurred in my honour!'(Carey, 2008: 200).

Some compliment, some honour! What Van Braam did not realise was that these contests had a deeper meaning. Whereas for a visiting European dignitary like himself, a tiger and buffalo fight might have been seen as a rather gruesome form of entertainment, the equivalent of bear-baiting or bull fighting in Europe, for the watching Javanese the contests had a much more profound significance. They equated the Europeans with the quick and deadly tiger and themselves with the powerful wild buffalo. Although the former was ferociously aggressive, it had no staying power and was nearly always defeated by its slower, more cautious and resilient adversary. In this particular case, both rounds had shown the Dutch 'tiger' in a rather unflattering light: in the first, although able to move in for the kill with the buffalo's tendons severed, it had not done so. In the second, the tiger had jumped clean out of the ring. Did this not mean that the Javanese could expect some unusual developments in terms of their Dutch adversary? At the time of Van Braam's visit, the British invasion still lay nearly three years away, but when it happened, those Yogyakarta courtiers who could recall the October 1808 tiger-and-buffalo fight on the southern alun-alun might have been forgiven for surmising that it presaged a time when the once mighty Dutch and their now defunct East India Company would be placed completely hors de combat as far as their rule in Java was concerned by a new and more formidable European enemy.

\section{The British Interregnum, 1811-1816}

News that the British were planning an invasion of Java was known in Java soon after the fateful tiger-and-buffalo fight in Yogyakarta. In late 1810, a returned Mecca pilgrim from Java's north coast, Haji Mustapa, who appears to have witnessed the British naval build-up in Melaka and Pulau Pinang, was 
arrested by the Franco-Dutch authorities for spreading rumours of an imminent British attack (Carey, 1992: 215). At the same time, the future British lieutenantgovernor of Java sent secret letters to various Indonesian rulers from Melaka announcing that the British would be coming to help them 'make an end' of everything associated with the Dutch and the French in Java and the eastern archipelago (Adam, 1971, Carey, 2008: 280). With the fall of the last FrancoDutch stronghold in the Indian Ocean, Mauritius (Île-de-France) on 7 December 1810 , the way was clear for a full-scale attack on Java. The Javanese elite would now experience Britain at its imperial zenith, what historian Chris Bayly has termed that island nation's 'imperial meridian' (1780-1830) (Bayly, 1989). They would also find that they had exchanged one form of colonial tyranny for another, no longer a Napoleonic Marshal this time but a 'virtual Napoleonic philosopher' and instinctive authoritarian, Thomas Stamford Raffles, a man 'who had a strong distrust of the [native] chiefs and a desire to rule autocratically' (Bastin, 1957).

Appearing off Batavia on 3 August 1811, the British expedition consisting of over 10,000 seasoned troops - half British line regiments and half Bengal sepoy battalions and Madras horse artillery -were an altogether more impressive army than Daendels' hastily gathered force, two-thirds of whom were raw local recruits. Despite the obvious mismatch, the British-Indian attackers appear to have conducted themselves with extreme ruthlessness. This can be seen from the name of the swamp - 'the swamp of the corpses' (Rawa Bangké, now Rawa Mangun) - into which they flung the dead after they had overrun Daendels' great redoubt at Meester Cornelis (present-day Jatinegara) on 26 August 1811. Casualty figures ran as high as 50 percent for the European defenders and 80 percent for the local Javanese and Madurese auxiliaries (Carey, 2008: 283). This was more a battue than a battle. During the six-week campaign the Franco-Dutch force lost over 10,000 men. Such behaviour, occasioned perhaps by the ideological nature of the conflict in which the British were engaged, namely the overthrow of French Republicanism and the restoration of pre-Revolutionary monarchical principles in Europe, gave the lie to the enlightened and liberal ideals proclaimed by the Governor-General of India, Lord Minto (in office, 1807-13), following the Meester Cornelis engagement:

'The inhabitants of Java now touch the fortunate moment when they will be placed under the protection of a power which will keep the calamities and sufferings of war far from their shores and under the guardianship of a just and beneficent government whose principle it is to combine the interests of the state with the security, prosperity and happiness of every class and denomination of the people. Let the people prove itself worthy of those blessings by a timely display of grateful zeal and obedience.'(Carey, 2008: 285).

Such 'shock and awe' continued when the British turned their attention to Yogyakarta which they took by storm in a three-hour operation which began at first light on 20 June 1812. Even Raffles admitted that while British casualties were light, losses amongst the Javanese defenders had been 'dreadful'. The body 
of the Javanese commander, who was tracked down and killed in his private mosque, was intentionally mutilated (Carey, 2008: 340).

This was the first time in Javanese history that a European force had overrun a kraton, and the plundering went on for four whole days, an unending stream of booty being carried to the Residency on ox-carts and on the backs of porters. In India, booty was one of the major perquisites of East India Company officers and the British army in India had fought for the right to keep everything in fortresses, courts and strong points taken by assault. Yogyakarta was no exception. Raffles referred briefly to this process in a dispatch to Lord Minto written soon after the fall of the kraton:

'The whole of the tangible property of Djocjocarta fell to the captors [...] but in the immediate distribution they took more upon themselves than was justifiable. [...] I had no reason to expect so hasty and hurried a measure on their part, but the mischief being once done, it was useless to object or condemn.[...] The universal opinion [has been] that in places carried by assault the army was entitled to make an immediate distribution of treasure and jewels, and the authority of Lord Cornwallis [governorgeneral of India, 1786-1793/1805] as well as the precedent of Lord Lake [commander-in-chief of the Indian Army and conqueror of Scindia during the Second Mahratta War, 1803-1805] were considered decisive'(Carey, 2008: 347).

In vain, did the lieutenant-governor cite the example of Lord Wellesley (governor-general of India, 1797-1805), who had tried - but failed - to prevent the army helping itself to the massive booty from the treasure of Tipu Sultan of Mysore (reigned, 1782-1799), when his fortified capital at Seringapatam was stormed in 1799 at the end of the Fourth Anglo-Mysore War (1798-99).

The treaties signed between the British government and the courts on 1 August 1812 gave legal title to the radically altered political environment in which the south-central Javanese kraton were now forced to exist. The new treaties, the lieutenant-governor averred, would place the south-central Javanese courts 'on such a footing as might no longer endanger the tranquillity of the country' and would open up their administrations to significant liberalisation and reform (Carey, 2008: 377). The annexation of these eastern outlying provinces, many of which had earlier been demanded by Daendels, meant that numerous - but not all - Yogyakarta and Surakarta provincial administrators (bupati) lost their positions and livelihood, for the British government only wanted to retain officials from the rank of sub-district head downwards.

The introduction of Raffles' land tax scheme into these annexed regions and the lieutenant-governor's over-optimistic view of their productive capacity Kedhu in particular - resulted in great hardship for the local population. Not only were the tax demands pitched too high, but the population - particularly those with dry fields - were also required to pay in cash - preferably silver - rather than in kind. This forced them into the hands of Chinese moneylenders who charged 
extortionate interest, an issue which we will return to shortly. At the same time, many of the previous dues and personal services expected by the local Javanese officials remained in force (Carey, 2008: 383). Raffles' land annexations in August 1812 exacerbated social problems at the courts and in Javanese society more widely which would later manifest in the breadth of support for Diponegoro at the time of the outbreak of the Java War.

There was one further clause in the treaties which bore even harder on the local population of the princely states. This was article eight, which stipulated that all foreigners and Javanese born outside the Principalities should henceforth fall directly under European government jurisdiction and be tried according to Government law (The late Dutch legal historian, G.J. ('Han') Resink (1911-97), defined 'government law' as a mixture of Javanese customary law (adat) and Dutch colonial law, the latter being described by Raffles as 'the laws of the Dutch States General and the statutes passed in Holland and Batavia with particular application to Java'). Raffles stressed that the article was specifically designed to afford protection to the Chinese and to ensure that they received their legal rights. But this seemingly innocuous provision had far-reaching consequences, in particular for the inhabitants of south-central Java. After February 1814, when the Resident's courts were established, all litigation between these inhabitants and the Chinese, as well as foreigners or subjects born outside the territories of the south-central Javanese kraton, was tried under Government law and not under Javanese-Islamic law. This meant that Javanese plaintiffs and defendants hailing from the sultan's and Sunan's dominions, who became involved in litigation with non-Javanese or those Javanese born in Government territories, were forced to have their cases tried under legal norms and law codes of which they had no personal knowledge or understanding.

Raffles' 1812 treaty, his subsequent legal reforms and the question of the sovereignty of Javanese-Islamic law in criminal cases would all prove significant in the later context of the Java War. Unlike the issue of Islamic religious practice, which tended to divide Diponegoro's court and santri (student of religion) supporters, the former favouring a rather less strict observance than the latter, British moves against the competence of the royal and religious courts in criminal cases united the two groups. Diponegoro's demands to be recognised as the regulator of religion with special competence over issues of criminal justice had widespread resonance.

The 1812 treaties were a disaster for the south-central Javanese courts. Not only did they involve a significant reduction in their territory, but they also left a potentially dangerous long-term social and economic legacy, especially in Yogyakarta. Here the combination of the fall of the court, the plundering of its treasury, artefacts and archives, and the imposition of Raffles' treaty, all dealt a shattering blow to the prestige and charisma of the court. Besides the financial and territorial losses, the looting of the kraton was undoubtedly felt at a deep psychological level by most Yogyanese. In previous Javanese history, such an 
event had usually signified that the court had been irredeemably defiled. The loss of magical power which such a defilement entailed usually necessitated the removal of the court site to another place. This had happened after the fall of Plérèd in June 1677 and Kartasura in June 1742. But there seems to have been no attempt to move the Yogyakarta kraton after June 1812, a seemingly fateful month for the fall of Javanese courts. Besides, the sultanate did not have the financial resources even if it had wished it. The sense of shame and disappointment at the events of 1812 persisted however. There are references in the Javanese sources that even before the British attack some held the view that the court's lustre (cahya) had been so tarnished that a move was essential (Carey, 2008: 254). The aged Pangéran Ngabèhi, elder brother of the exiled second sultan, probably spoke for many when he referred to the surrender of his personal kris (stabbing dagger) at the time of the British assault as a form of castration (Carey, 1992: 90). The British confiscation of all the kris of the senior Yogyakarta officials and princes would certainly have been experienced as a form of unmanning given the special symbolic importance of the kris in Javanese culture where the weapon can represent the presence of a male owner at a wedding.

Later, following the second sultan's restoration (17 August 1826) and return to the kraton (21 September 1826) during the Java War, some of the letters written to him by Yogyakarta princes, who had joined Diponegoro, dwelt on the sense of shame they had experienced in witnessing his treatment at the hands of the British and the humiliation of the plunder of the kraton (Louw, 1897: 685687). These feelings of humiliation and bitterness towards the Europeans were to deepen during the fourth sultan's reign (1814-22) when the political and economic influence of the European government in the princely territories became ever more pronounced. They put in perspective the attempts by Diponegoro early in the war to bring about the final destruction of the Yogyakarta kraton and to establish a new undefiled kraton at another site. 'All Java knows this', Willem van Hogendorp would later write, 'how the Dutch allowed the kraton [of Yogyakarta] to be turned into a brothel and how Diponegoro has sworn to destroy it to the last stone and expel the [European] landowners who have driven out the Javanese officials'(Carey, 2008: 389). The yearning for moral regeneration under the banner of Islam and the restoration of the sultanate's prestige became significant themes in the years preceding the Java War and go far to explain why so many members of the Yogyakarta court rallied to Diponegoro in 1825 .

\section{The Role of the Chinese}

The plight of the Chinese in south-central Java at the time of the outbreak of the Java War in July 1825 was due in large measure to another aspect of the British administration - continued by the returned Dutch administration after August 1816 - which contributed to the rising unrest in the south-central Javanese countryside. This was the working of the tollgates (bandar). In the space of just 
twelve years (1812-1824), following the British take-over in August 1812, the revenue received by the colonial government from the bandar in the Yogyakarta territories alone nearlyquadrupled (Carey, 2008: 834-839). Thesestopping places, which were positioned a day's journey on foot from each other, were frequented by Chinese merchants, some of whom had bought the right from the local captain of the Chinese or kapitan cina to levy tolls from other travellers for looking after their goods and belongings overnight. Over time, a fully fledged bandar would be established run by a Chinese tollgate keeper. Sometimes a market would also develop from the wayside stalls (warung) serving the overnight shelter. Then, as the Chinese bandar became more familiar with the surrounding countryside and greater pressure was put on him by his kapitan cina to pay higher rents, smaller tollgates (rangkah) would be set up on adjacent country lanes. Observation posts (salaran) were also constructed on the borders of the customs' districts controlled by the separate bandar to check that the requisite taxes had been paid before traders passed into a new zone. These developments were accelerated by the rise of regional trade in the seventy years of peace which followed the Giyanti treaty of the mid-eighteenth century. So much so that just before the outbreak of the Java War, in the words of the Dutch commissioners charged with enquiring into the administration of the principalities in 1824 , 'there was a tollgate at the entrance of nearly every village and hamlet'(Arsip Nasional Republik Indonesia, henceforth: ANRI).

A senior Dutch official Jan Isäak van Sevenhoven (1782-1841), who considered the tollgates along with the porters' guilds as the two greatest evils of pre-war Javanese peasant society, gave a depressing account of the sort of scene which became an all too familiar occurrence at tollgates throughout south-central Java in this period. He described how a Javanese on the way to market would be forced to wait for hours in a queue before his load was inspected. If his buffaloes grazed on the tollgate keeper's land during this time, he was fined and if this fine was not paid his draught animals were impounded so that at harvest time it was not uncommon for a Javanese farmer to surrender the bulk of his profits to cover the rent of his own animals from the local Bandar (van Kesteren, 1892: 973-96). When the peasant cultivator's turn came for his load to be inspected, the tollgate keeper would browbeat him and demand that he hand over a large percentage payment on his goods for right of passage. The peasant cultivator would then throw himself at the tollgate keeper's mercy: 'Ampun tuwan ['Have mercy, Sir!'], my family is poor!'. But if he refused payment, he ran the risk of having his entire load confiscated. During the long hours of waiting, the farmer would often be tempted to take opium which was readily available at the bandar and usually retailed by the keeper as an additional income source. In the event of an overnight stay, there would be the added beguilement of ronggèng (dancing girls, prostitutes) and gambling parties which would further eat into the farmer's meagre savings. If he had serious ill-luck at cards, the farmer would often be forced to part with his clothes and even the money, which many Javanese traders 
and peasant cultivators borrowed from their village heads to cover the cost of the toll dues. In such a situation, it was not uncommon for a peasant cultivator to take to a roving life as a bandit or porter on the roads rather than face the ignominy of returning empty-handed to his village (KITLV H 503, Van Sevenhoven, 'Aanteekeningen', p.77; AvJ, G.A.G.Ph. van der Capellen (Batavia/Bogor) to A.H. Smissaert (Yogyakarta), 9-5-1824).

Appeals to local Javanese officials about abuses of power by the tollgate keepers were usually unavailing because the officials themselves were given cash gifts to ensure they overlooked extortionate practices. In addition, a journey to the court towns to put a case before the Residency court was usually beyond the means of the average farmer. The only way a 'little man' (wong cilik) could revenge himself on a tollgate keeper would be by enlisting the help of local bandits and getting them to plunder the bandar or burn it to the ground. Such cases of burglary and arson occurred with increasing frequency in the years before the Java War as can be seen from the rising value of goods stolen from the tollgates (MvK 4132, MacGillivray, 'Nota', 13-5-1826 gives the following figures for the value of goods stolen from the bandar in the period 1817-24: 1817: $f$. 2,278; 1818: f. 3,005; 1819: f. 2,442; 1820: f. 4,240; 1821: $f .8,791 ; 1822: f .15,623 ; 1823$ : $f .15,660 ; 1824: f .32,100)$. Many Chinese tollgate keepers also lost their lives. This situation became desperate following the outbreak of the war when all the tollgates in the vicinity of Yogyakarta were burnt to the ground (Carey, 1984: 1-2, Archief Nationaal (The Hague) H.M. de Kock private collection (henceforth: dK) 197, A.H. Smissaert (Yogyakarta) to H.M. de Kock (Surakarta), 30-7-1825). But popular retribution such as this often spelled disaster for the inhabitants of neighbouring villages, which, under the terms of the Javanese criminal codes, were liable to pay an indemnity amounting to two-thirds of the value of any stolen goods or a 'blood price' (diyat) - which was double the amount for a dead Chinese than for a Javanese - to the family of the murdered man if the crime could not be resolved satisfactorily (Soeripto, 1929: 88, 268, Carey, 1980: 126-128).

Faced with thethreat of constant attack, thetollgate keepers began to organize their own 'private armies' of bodyguards and thugs, some of them recruited from former sepoys, thus adding another twist to the spiral of violence in country areas as the Java War loomed (Carey, 1981: 243). Even when Van Sevenhoven was first writing just before the British take-over of the tollgates in August 1812, the potential that they might develop into a serious impediment to trade in south-central Java was already evident. Twelve years later, when he served as commissioner enquiring into the administration of the principalities, the bandar had become so effectively sited that nothing could be transported on the roads without going through one. If a Javanese tried to evade a tollgate by taking a cross-country route, the tollgate keeper's spies would usually report his action resulting in the forfeiture of his goods (S.Br.170, Commissioners (Yogyakarta/Surakarta) to G.A.G.Ph. van der Capellen (Batavia/Bogor), 24-10-1824). The increase in customs' posts had a significant effect on the price of foodstuffs in south-central Java. Nowhere was this more 
evident than in Yogyakarta where prices of rice and other necessities were nearly double those in Surakarta, which benefited from cheap transport costs for bulk goods along the Bengawan Sala (Solo River).

The colonial government was perfectly aware of the harmful effects of the tollgates and it made some moves to restrict their influence before 1825. The British abolished the bandar along the Solo River in February 1814 and the Dutch followed suit in Kedhu in 1824, a move which led to an immediate increase in the number of markets and the level of trade in the province (Archief Nationaal (The Hague), G.J. Schneither private collection 92, Pieter le Clercq, 'Algemeen verslag der Residentie Kadoe over het jaar 1824', 30-5-1825. The bandar along the Brantas and Madiun rivers were also abolished in December 1823, KITLV H 395, Chevallier, 'Rapport', 13-6-1824). In the same year, Governor-general Van der Capellen appointed a three-man team of commissioners headed by the Residents of Yogyakarta and Surakarta and including Van Sevenhoven, soon to take over as Resident of Surakarta (in office, 1825-1827), to enquire into the working of the tollgates in the Principalities. The team reported back in October 1824 unequivocally recommending the abolition of all internal customs posts and suggesting that the European government should indemnify itself for the lost revenue - estimated at about a million Indies guilders - by annexing the western outlying provinces of Bagelèn and Banyumas. They also urged that all Chinese resident in villages and hamlets should be ordered to move to the royal capitals, that every unmarried Chinese who had been in the Principalities for less than two years should be expelled forthwith, along with those who were unemployed or guilty of extortion, and that no new Chinese immigration should be allowed (S.Br.170, Commissioners (Yogyakarta/Surakarta) to G.A.G.Ph. van der Capellen (Batavia/Bogor), 24-10-1824). As one of the commissioners, Hendrik Mauritz MacGillivray (1797-1835), later put it:

'The Chinese are our work tools and although each year we rejoice over the increased [tax revenues] which are ascribed to [increased] prosperity and welfare, we bind the iron yoke more firmly on the shoulders [of the Javanese] [...] for a million guilders a year worth of taxes we compromise the welfare and happiness of almost two million inhabitants who are not immediately under our protection [...] but whose interests are so clearly linked to ours (Kemp, 1896: 386, MvK 4132, MacGillivray, 'Nota', 13-5-1826. See further P.J.F. Louw, De Java-oorlog van 1825-30 ('s-Gravenhage/ Batavia, 1894), I:13).'

Only the 'good nature and peacefulness' of the Javanese, in the commissioners' opinion (Scholten and A. Niehof, 1987: 12-42), ${ }^{2}$ had enabled the oppression of the tollgate system to continue for so long. They ended with a fearful prophecy:

2 The Commissioners' remarks about the 'good-natured and peaceful Javanese', who were liable to run amok if aroused, constitute a classic expression of the widespread and self-deluding Dutch colonial view of 'De Javaan als het zachste volk ter aarde' (the Javanese as the gentlest people in the world). 
'We hope they [the Javanese] will not be awoken out of their slumbering state, for we reckon it as a certainty that if the tollgates are permitted to continue, the time is not far distant when the Javanese will be aroused in a terrible fashion (S.Br.17o, Commissioners (Yogyakarta/Surakarta) to G.A.G.Ph.van der Capellen (Batavia/Bogor), 24-10-1824.).'

Despite the dire warnings of imminent agrarian unrest from nearly every official who studied the problem, the post-1816 Dutch administration felt it could not forego the lucrative tollgate revenues from the Principalities (van der Kemp, 1896: 44-45). The nearly threefold rise in annual profits from the tollgate farms in Yogyakarta between 1816 and 1824 seems to have made the senior officials in the Finance Department in Batavia blind to the fact that the bandar were inexorably paralysing trade. Writing in November 1824, a mere two months after taking over the once profitable tollgates of Bantul and Jatinom to the south of Yogyakarta, the local Chinese tollgate keeper reported that he had become bankrupt (Dj. Br.59, Gan Hiang Sing (Bantul) to A.H. Smissaert (Yogyakarta), 9-11-1824.). A prolonged and severe drought since the beginning of the year had destroyed the cotton crop and basic foodstuffs such as castor-oil plants, soy beans and maize were in short supply. Rice prices were soaring but little trade was being carried on in the local markets because commerce had effectively collapsed.

In these terrible months before the Java War, the south-central Javanese countryside became a place of suspicion and terror. Armed gangs operated with virtual impunity, murders were rife and the daily activities of the local peasant cultivators took place under the ever-watchful eyes of the tollgate keepers' spies who were positioned on every village and country road to prevent the evasion of toll dues. Even the dead on their way to burial were liable for imposts, and mere passage through a tollgate even without dutiable goods, would expose the traveller to what the Javanese sarcastically came to refer to as the 'bottom tax' (pajak bokong) (KITLV H 395, Chevallier, 'Rapport', 15-6-1824). Neither were high-placed Javanese officials exempt. The Secretary (Assistant-Resident) of Yogyakarta, Pierre Frederic Henri Chevallier (1795-1825), remarked how the grey-haired bupati of Nganjuk, a district in the Surakarta eastern mancanagara, remarked wrily that he was less fearful of the tigers infesting the teak forests on his cross-country journeys to the Sunan's capital to attend the Garebeg festivals than he was of the bare-faced thugs who manned the tollgates on the NganjukSurakarta highway (KITLV H 395, Chevallier, 'Rapport', 15-6-1824). Other Javanese officials spoke with scarcely concealed contempt of the obscene way in which their wives and daughters were physically searched for items of jewellery by Chinese bandar newly arrived from the maritime provinces of China who were barely conversant in Malay (KITLV H 395, Chevallier, 'Rapport', 15-6-1824).

The Dutch now began to refer to the Chinese as 'a race of customs house keepers' in their reports echoing the common Javanese expression for them as 'tollgate people', the expression in the Dutch original was 'linie van douanen'. The 
Javanese phrase was 'bangsa bandar'. (S.Br. 170, Commissioners (Yogyakarta/ Surakarta) to G.A.G.Ph. van der Capellen (Batavia/Bogor), 24-10-1824). Huibert Gerard Nahuys van Burgst (1782-1858), who served as both Resident of Surakarta (1820-22) and Yogyakarta (1816-23) meanwhile, noted that barely one Chinese in twenty who came to the Indies from China ever returned to the place of their birth so rich were the pickings in Java (S.Br. 122, H.G. Nahuys van Burgst (Yogyakarta) to G.A.G.Ph. van der Capellen (Batavia/Bogor), 29-91822.). Yet not all Chinese were by nature oppressors. Before the post-1816 Dutch administration had ratcheted up its fiscal demands to intolerable levels, there were a number of favourable reports of the behaviour of Chinese tax-farmers. During the British period, the principal Chinese land-renter in Wirasaba in east Java, Lib Sing, who controlled over 200 villages, was reported to have been 'a kind and indulgent master' under whom the wong cilik or common people liked to take service because 'the lands and villages in his area were better looked after than elsewhere'(IOL, Mackenzie Private collection 21 part10, Lt. H.G. Jourdan, 'Report on Japan and Wirosobo', 28-4-1813, 361). Similar reports were made of the Chinese land-renters of Ulujami near Pekalongan on the north coast, the 'rice granary' of Semarang (Carey, 1984: 17, Ong Tae Hae, 1849: 13) . Even Chinese tollgate keepers were praised. In May 1812, during his journey across Java, Van Sevenhoven noted that the Chinese bandar at the ferry crossing at Kreteg on the Opak River to the south of Yogyakarta 'seemed the very best sort of tollgate keeper', whose subordinates 'appeared healthy and robust'(KITLV H 503, Van Sevenhoven, 'Aanteekeningen', pp.135-6.). What had changed in the post-1816 period was not the character of the Chinese but the character of the fiscal regime they served. And for this the post-1816 Dutch administration must take full responsibility.

Although Van der Capellen's government was principally responsible for the sharp rise in tollgate and market revenues after 1816, the British were the midwives to another equally disastrous development - the rapid extension of the opium retail trade. The greater ease of opium imports from Bengal following the lifting of the British blockade of the archipelago in August-September 1811 and the financial pressures on Raffles' government were the key reasons (J.J. Hasselman, 1858: 18-37). Once again, the Chinese came to assume a prominent and invidious role as farmers and retailers, opium retail and tollgate farming often going hand in hand.

The statistics for official opium sales in the Principalities reflect the sharp increase in opium consumption which began in the British period. Between 1802 and 1814 sales doubled from 40 chests of 148 avoirdupois pounds to 80, by which time the wholesale value of a chest had increased twofold due to the effects of inflation, the tightness of the British naval blockade (1804-1811), and the more stringent British enforcement of the opium monopoly after they assumed control of Java in August 1811. During the 1814-1824 decade, revenue from the Yogyakarta opium farm multiplied five times. By 1820 there were 372 separate places licensed 
to retain opium in the sultan's territories, namely, nearly every major tollgate, subtollgate and market in the sultanate. The exact number of opium addicts is difficult to ascertain. On the basis of consumption figures compiled in the late nineteenth century, a Dutch official estimated that some sixteen percent of the 20-million strong Javanese population took opium (J.J. Wiselius, 1886: 6). But if one counts all those who inhaled and digested 'poor men's' varieties of the drug, such as opium-soaked cigarettes, opium-seasoned coffee, and opium-laced betelnut, the incidence of narcotic consumption was almost certainly very much higher (James Rush, 2007: 26-30). Raffles, for example, distinguished between the crude opium or manta 'eaten' by people in the interior of Java, particularly in the Principalities, and the prepared opium referred or madat/candu smoked extensively along the north coast (Raffles, 1817: 102-102). During his journey through south-central Java in May 1812, Van Sevenhoven remarked on the widespread use of opium amongst the members of the porters' guilds and unemployed labourers in the court towns. He also noted how the tollgate opium outlets had spread the habit amongst Javanese in the countryside (KITLV H 503, Van Sevenhoven. 'Aanteekeningen', p.73.). As he passed through the usually bustling market of Klathèn one morning, he noticed how full the opium dens were and how threadbare their inhabitants: some were barely clothed, others were dressed in worn-out kain (wrap-arounds) (KITLV H 503, Van Sevenhoven, 'Aanteekeningen', pp.79-80). One and a half cents was enough, on average, to purchase a small wad of opium-soaked tobacco, containing at the most 76 milligrams of opium, which represented about 15 percent of a porter's daily wage at this time (Carey, 1984: 35). For many it offered the only release from a life of unrelieved toil and hardship. In Pacitan, in the immediate post-Java War period, a huge religious feast (slametan) would be held to celebrate the end of the coffee harvest when crop payments would go on 'opium eating' (Kern, 1908: 163). The drug was also used widely as a stimulant and as a valued part of the Javanese pharmacopoeia for treating various ailments (Rush, 2007: 34). During the Java War, there were reports that many of Dipanagara's troops had 'fallen sick' for want of opium, and Chinese peddlers did a brisk trade behind the prince's lines when the violent sinophobe sentiments of the first months of the war had abated somewhat (Carey, 1984: 610). Several Yogyakarta princes and high officials also acquired a taste for the opium pipe, and princely addicts were noticed amongst Dipanagara's followers at his headquarters at Selarong in late July and early August 1825 (Carey, 1984: 480).

A pastime for the rich, opium addiction was a disaster for the poor. Even the slightest predilection for the drug would exhaust the scarce savings of the Javanese peasant and made his already difficult economic position even more precarious. The road to social degradation and crime was ever present. Nahuys recognised this during the Java War when he called for the rounding up of the thousands of landless labourers and footloose vagrants in south-central Java, 'men with no ricefields whose [thin] shoulders and smooth hands bear no marks of labour and whose eyes, lips and colour betray the habitual use of narcotics 
(Universiteits Bibliotheek Leiden, Bibliotheca Publica Latina 616 Portfolio 9 part 3, H.G. Nahuys van Burgst, 'Onlusten op Java', Maastricht, 1826).' The social consequences of opium addiction and the increasingly salient role played by the Chinese as retailers were yet another strand in the rapidly deteriorating socioeconomic conditions in south-central Java in the post-1816 period. Along with the tollgates, the opium farm lay at the heart of the rise in anti-Chinese sentiments amongst the Javanese population in the decade before the Java War. Attacks on Chinese tollgate keepers and merchants would become an increasingly salient feature of popular movements in south-central Java as the war neared.

\section{Conclusion}

The humiliations experienced by the Yogyakarta elite at the hands of the Dutch and the British were the inevitable outcome of their inability to come to terms with the reality of the new European colonialism born of the twin industrial and bourgeois democratic revolutions which had convulsed the Atlantic world in the late eighteenth century. The changes had been introduced into Java too rapidly and in too brutal a fashion. In the space of just under four years, the south-central Javanese courts had been forced to accommodate themselves to a new form of centralised colonial government which stood in direct contradiction to their own political philosophy of divided sovereignty in Java. Given time, they might have been able to reshape their political conceptions to legitimize the changed realities, but they could not do it in the quick fire way demanded by Daendels and Raffles. The result was disaster. This was particularly the case for Yogyakarta, which had entered on this period of cataclysmic change with ostensibly the most powerful and prosperous court, but in fact hopelessly divided against itself and ruled by a vain and inflexible man. The rapid germination of intrigues within the court literally tore it apart just at the time when it needed its undivided energies to cope with the new challenges posed by a resurgent Europe. The Yogyakarta sultanate had been founded by the sword in the mid-eighteenth century. In June 1812, it could be said to have perished by the sword.

For the British colonial government in Java, there was little doubt about the significance of their victory. Raffles' exceedingly able Dutch assistant, Harman Warner Muntinghe (1773-1827), who later took British citizenship, hailed it as an event of similar significance to Robert Clive's victory at Plassey in June 1757 which had opened up the whole of northern India to British rule. Raffles echoed this in a

dispatch to his patron, Lord Minto, when he stated that 'the European power is for the first time paramount in Java. [...] we never till this moment could call ourselves masters of the more valuable provinces in the interior, nay, our possessions on the sea coasts would always have been precarious and, had [our] military force been materially reduced, much eventual danger was to be apprehended (Carey, 1984: 342-343). Although both Yogyakarta and Surakarta would continue as dismembered states after 1812, they were never again in themselves capable of 
posing a threat to the position of the European government. When a new challenge did materialise under Diponegoro's Javanese-Islamic banner in July 1825, it would owe its inspiration and energies to influences outside the great court traditions. The support given to the prince by the religious communities and the Javanese peasantry, both groups who felt themselves increasingly excluded from the new colonial order and oppressed by the Chinese-run tollgate system, was more important than the traditional foci of court patronage and loyalty. In many ways, June 1812 rather than the end of the Java War should be seen as the date when the new colonial era dawned in Java. Out of this collapse and the legacy of bitterness which it left, however, a new and more potent combination of elements in Javanese society would emerge. It would bring the restored Dutch colonial regime close to destruction at the start of the Java War and lay the foundations for the future Indonesian nationalist movement of the early twentieth-century. A turning point as significant as any in the colonial era, it would set the course of Indonesian history for the next 150 years.

\section{REFERENCES}

Ahmat bin Adam. (1971). A descriptive account of the Malay letters sent by Thomas Stamford

Bastin, John. (1957). The native policies of Sir Stamford Raffles in Java and Sumatra; an economic interpretation. Oxford.

Bayly, C.A. (1989). Imperial meridian: The British empire and the world, 17801830. Harlow

Carey, P. (2008). The Power of Prophecy: Prince Dipanagara and the End of an Old Order in Java (1825-1830). Leiden

Carey, P (ed). (1992). The British in Java; A Javanese Account, 1812-1816. Oxford,

Carey, P.B.R (ed). (1980). The archive of Yogyakarta. Vol. I: Documents relating to politics and internal court affairs. Oxford: Oxford University Press

Carey (ed). P.B.R. (1981). Babad Dipanagara. An Account of the Outbreak of the Java War (1825-30). Kuala Lumpur.

Carey . (1984). Changing Javanese perceptions of the Chinese communities in Central Java, 1755-1825. Indonesia .

C.E. van Kesteren, 'Waarschuwingen vóór den Java-oorlog', De Indische Gids

Daendels, H.W. (1814). Staat der Nederlandsche Oostindische bezittingen, onder het bestuur van den Gouverneur-Generaal Herman Willem Daendels, ridder, luitenant-generaal \&c. in de jaren 1808-1811. 's-Gravenhag.

E. Locher-Scholten and A. Niehof (eds.). (1987). Indonesian women in focus; Past and present notions. Dordrecht/Providence

Hasselman, J.J. (1858) 'Nota omtrent de opium-pacht op Java en Madoera', Handelingen en Geschriften van het Indisch Genootschap. 
Hoffman, J. (1979). A Foreign Investment: Indies Malay to 1901. Indonesia

J.K.J. de Jonge and M.L. van Deventer (eds). (1888). De Opkomst van het Nederlandsch Gezag in Oost-Indië: verzameling van onuitgegeven stukken uit het oud-koloniaal archief.'sGravenhage.

Kern, R.A. (1908).“Uit oude beschieden (geschiedenis van de afdeeling Patjitan in de eerste helft der 19e eeuw) met bijlage', Tijdschrift van het Binnenlands Bestuur

Louw, P.J.F. (1897). De Java-Oorlog van 1825-30. 's-Gravenhage/ Batavia.

Ong Tae Hae. (1849). The Chinaman abroad; Or a desultory account of the Malayan Archipelago, particularly of Java. ed. and trans. W.H. Medhurst. Shanghae

P.H. van der Kemp (ed). (1896). 'Brieven van den Gouverneur-Generaal Van der Capellen over Dipanagara's opstand zoomede eene wederlegging van den Minister Elout', Bijdragen tot de Taal-, Land-en Volkenkunde .

Raffles. (1817). History of Java. London.

Rush, James. (2007). Opium to Java; revenue farming and Chinese enterprise in colonial Indonesia 1860-1910. Jakarta

Schama, S. (1977). Patriots and Liberators: Revolution in the Netherlands, 17801813. London,

Soeripto. (1929). Ontwikkelingsgang der vorstenlandsche wetboeken. Leiden: Eduard IJdo,

V. Houben. (1994). Kraton and Kumpeni: Surakarta and Yogyakarta 18301870. Leiden

van der Kemp. (1896).Dipanegara, eene geschiedkundige Hamlettype', Bijdragen tot de Taal-, Land-en Volkenkunde.

Wiselius, J.J.. (1886), De opium in Nederlandsch- en Britsch-Indië, economisch, critisch, historisch.T he Hague

\section{Archive}

KITLV H 503, Van Sevenhoven, 'Aanteekeningen', p.77; AvJ, G.A.G.Ph. van der Capellen (Batavia/Bogor) to A.H. Smissaert (Yogyakarta), 9-5-1824.

Archief Nationaal (The Hague) H.M. de Kock private collection (henceforth: dK) 197, A.H. Smissaert (Yogyakarta) to H.M. de Kock (Surakarta), 30-7-1825.

S.Br.170, Commissioners (Yogyakarta/Surakarta) to G.A.G.Ph. van der Capellen (Batavia/Bogor), 24-10-1824

KITLV H 503, Van Sevenhoven. 'Aanteekeningen', p.73.

S.Br.170, Commissioners (Yogyakarta/Surakarta) to G.A.G.Ph. van der Capellen (Batavia/Bogor), 24-10-1824.

Archief Nationaal (The Hague), G.J. Schneither private collection 92, Pieter le Clercq, 'Algemeen verslag der Residentie Kadoe over het jaar 1824', 30-51825. The bandar along the Brantas and Madiun rivers were also abolished in December 1823, KITLV H 395, Chevallier, 'Rapport', 13-6-1824 
S.Br.170, Commissioners (Yogyakarta/Surakarta) to G.A.G.Ph. van der Capellen (Batavia/Bogor), 24-10-1824.

MvK 4132, MacGillivray, 'Nota', 13-5-1826. See further P.J.F. Louw, De Javaoorlog van 1825-30 ('s-Gravenhage/ Batavia, 1894), I:13

Dj.Br.59, Gan Hiang Sing (Bantul) to A.H. Smissaert (Yogyakarta), 9-11-1824.

KITLV H 395, Chevallier, 'Rapport', 15-6-1824

S.Br. 170, Commissioners (Yogyakarta/Surakarta) to G.A.G.Ph. van der Capellen (Batavia/Bogor), 24-10-1824

S.Br. 122, H.G. Nahuys van Burgst (Yogyakarta) to G.A.G.Ph. van der Capellen (Batavia/Bogor), 29-9-1822.

IOL, Mackenzie Private collection 21 part1o, Lt. H.G. Jourdan, 'Report on Japan and Wirosobo', 28-4-1813, 361.

KITLV H 503, Van Sevenhoven, 'Aanteekeningen', pp.79-80

Universiteits Bibliotheek Leiden, Bibliotheca Publica Latina 616 Portfolio 9 part 3, H.G. Nahuys van Burgst, 'Onlusten op Java', Maastricht, 1826 